\section{The logic of security markets: Security governance in failed states}

Security Dialogue 42(6) 553-569 (C) The Author(s) 2011

Reprints and permission: sagepub. co.uk/journalsPermissions.nav DOI: $10.1177 / 0967010611424423$ sdi.sagepub.com

@SAGE

\title{
Željko Branović
}

Collaborative Research Center 'Governance in Areas of Limited Statehood', Berlin, Germany

\section{Sven Chojnacki}

Research Unit Peace and Conflict Studies, Free University Berlin, Germany

\begin{abstract}
This article presents a theoretical framework with which to discuss how non-state modes of security governance evolve in the context of state failure and/or collapse. To address this issue, we present the logic of security markets, which assumes that the evolution of security governance by non-state groups in failed states is a function of both resource availability and the strategies that armed groups apply to extract resources from the civilian population. Axiomatically, we expect that in the short term the central purpose for the use of force is survival and achieving the ability to finance one's capabilities to use force, although ultimately this also includes the seizure and control of territory. The main argument is that the changing competitive conditions in security markets - which we measure in terms of the total number of violent groups and their organizational design, size and strength - explain the rationales behind the decisions of armed groups either to use violence against the civilian population or to invest in the provision of security.
\end{abstract}

\section{Keywords}

security governance, state failure, civil war, monopoly of violence, non-state actors, conflict theory, economic theory

\section{Introduction}

Security governance in zones of armed conflict and collapsed statehood seems like an antinomy. As a matter of fact, empirical evidence suggests that political disintegration and a lack of security guarantees frequently provide the rationale for local militias or rebel groups to pursue permanent strategies of violence, enrich themselves economically and thereby profit from insecurity. Accordingly, a vast literature emphasizes the destructive dimension of state failure and collective violence, but most studies do not recognize the potential evolutionary and alternative paths of security. As the rise of Somaliland or 'Taylor-Land' in Liberia during the 1990s has shown, the 
breakdown of a state does not necessarily result in permanent insecurity. Rather, at least two logics of strategic action emerge, comprising distinct but potentially overlapping security dynamics: first, strategic insecurity, characterized by a shortage of armed protection, the emergence of non-state armed groups and a lack of collectively binding rules; second, strategic security, which fulfils political, economic and identity-based functions within a given territory and provides for various degrees of scope and inclusiveness by various actors, such as civil defence groups, external military forces and private military companies.

While most studies within international relations theory, comparative politics and conflict research neglect the security activities of non-state actors in areas where state authority has collapsed, we pay attention to the security dynamics that emerge in areas of collapsed statehood. For theoretical reasons, we assume that security can be provided without the state, or even its most rudimentary structures, and that the governance approach can, in turn, be usefully applied precisely to the processes of partially institutionalized macro-networks of strategic security that obtain in such cases. This idea builds upon approaches that interpret the violent activity of non-state armed actors as 'new' forms of governance (Duffield, 2001; Jackson, 2003; Keen, 2000; Reno, 2000), thereby moving away from state-centred perspectives of security and relying on a more promising approach to governance.

By linking the use of force (war-making) and the formation of governance (state-making), as proposed by Olson $(1993)$ and Tilly $(1985,1990)$, scholars began to explore the idea that non-state armed groups might rather invest in the provision of political goods than pursue strategies of looting and violence against the civilian population (Kingston and Spears, 2004; Ottaway, 2002; Pegg, 1998; Stokke, 2006; Tull, 2004). However, from the governance perspective, one central question still remains: How do these modes of security governance evolve in the context of state failure and/ or collapse? To address this question, we present the logic of security markets, which is based on economic approaches and peace and conflict theory. The concept of the 'security market' refers to the spatial and temporal coincidence of the demand for and supply of security in areas where the means of violence are not monopolized. Building on the arguments of both Charles Tilly (1985, 1990) and Mancur Olson (1993), the logic of security markets assumes that the evolution of security governance by non-state groups in failed states is a function of (1) resource availability and (2) strategies that armed groups apply in order to extract resources from the civilian population. Uncontrolled and unregulated security markets entail specific dynamics that explain the outbreak of violence, as well as the preferred form for the institutionalization of security governance, as a resource-allocation mechanism. Axiomatically, we assume that the central goals for the use of force are survival in the short term and the ability to finance one's capabilities to use force. In the long term, though, they also include the seizure and control of territory.

The main argument is that the changing competitive conditions of security markets, which we measure as (1) the total number of violent groups and (2) their organizational design (size and strength), explain the rationale behind the decisions of armed groups either to use violence against the civilian population or to invest in the provision of security. By tracing the variance of these two variables, which we theorize as a function of open security markets in the wake of state collapse, we identify causal pathways to the formation of security governance extending beyond the state. Whereas state collapse opens the security market to non-state actors, who might enrich themselves and use violence in the absence of a sanctioning authority, in the long run the increase in the number of actors and their organizational demands creates a resource-allocation problem, as well as additional incentives to use nonviolent means of extraction and invest in the provision of security governance. These market-endogenous processes are accompanied by specific opportunity 
structures such as natural resources, geographic conditions or the degree of territorial control and power vis-à-vis other armed groups, which additionally shape the formation of preferences for the use of force. While not only focusing on the rationale behind the decisions of violent groups as to whether to initiate and perpetuate violent conflict (greed vs. grievance), but also theorizing as to the conditions and mechanisms by which these groups turn to the provision of security, our research adds an important dimension to the study of violence and security in failed states.

The article starts by assessing the concept of security governance and the characteristics of the security provided by armed groups in the context of state failure. In the second section, this mode of coercive security provision is discussed from the perspective of governance and the public good. In the third section, we proceed by connecting this mode of coercive security theoretically with the logic of security markets. The fourth section goes on to discuss three opportunity structures that frame the competitive conditions of security markets. The article finally closes with a discussion of the relationship between security and governance in failed states.

\section{Assessing the character of security in failed states}

The scientific debate assessing the forms and qualities of security in failed states has created a flood of definitions and conceptual controversies. While the collapse of communism and the transformation of the international security agenda at the end of the Cold War contributed to a broadening of the concept of security, 'security governance' became the magic term for denoting the changing security relations at different levels (international, national, subnational), between different actors (state and non-state actors), and with regard to the management of various threats (e.g. civil war, trans-border refugee flows). Consequently, some authors link security governance to overall developments in the fragmentation of political authority between state and non-state actors, and thereby to a variety of forms of coordination, including regulation, collaboration and selfregulation (see Krahmann, 2008). Other authors, in contrast, refer more explicitly to the function of governance structures as a means of managing social relations within civil wars (Öberg and Strøm, 2008: 9). Each perspective reflects changing forms and qualities of security, but has certain limitations regarding the assessment of the character of security in failed states. While the first assessment of security governance denotes the emergence of complex security structures in Europe and North America, and is thus not applicable to the processes of violence and the logics of nonstate action in the absence of a unifying political authority, the latter uses governance simply as a synonym for the formal and informal mechanisms of conflict resolution.

In contrast, we operate with a definition of governance that incorporates the regulatory structures and processes by which the security provided is intended as a collective good for a defined group of recipients. This definition emphasizes the specific strategies of militarily potent actors who invest in the establishment of monopolies in the use of force and advance processes of governance formation - that is, the establishment of institutionalized political and economic systems of rule. Within such security environments, one can assume the emergence of 'new' forms of governance within or across territorial boundaries (see Duffield, 2001; Jackson, 2003). As a result, we define security in a narrow sense, as the absence of threat to a predefined social group or, to put it differently, as a situation in which means applied with the purpose of maintaining protection against a specific group succeed in reducing the risk level with respect to existential threats.

Since security as a governance function must meet at least the criteria of a collective good (Risse and Lehmkuhl, forthcoming), the logic of its consumption should be discussed first: Which social groups actually consume security as a commodity and what territorial range does that 
consumption assume? In other words, what sort of character does security take in failed states, in terms of inclusiveness and rivalry (Krahmann, 2008)? According to the theory of public goods, a pure public good is non-excludable and non-rival in consumption (Samuelson, 1954; Stiglitz, 1999: 127-8). Strong states (see Rotberg, 2003) are assumed to monopolize the means of physical force (Weber, [1921] 1968). If militarily potent actors are/become able and willing to provide both internal security and protection against external threats through military and policing organizations, almost all citizens benefit from this arrangement as a public good (Rothschild, 1995; Sandler, 1993).

The territorial domain of the provision and the inclusiveness of the consumption are crucial to the evaluation of security as a public good. In failed states, the breakdown of state institutions usually leads to a societal fragmentation and the emergence of different violent groups that formulate political or economic claims. Organized violent groups might exist and challenge the state over different periods of time (Vreeland, 2008), but the complete collapse of state authority bears a special structural characteristic that marks that point in time to which the intrastate security dilemma (see Kaufman, 1996; Posen, 1993; Roe, 1999) becomes prevalent for the civilian population and opens the security market for additional actors/suppliers. In the absence of an effective central government, very different groups within a state (ethnic, national, political, religious) are forced to provide their own security, or at least to build up the capacities to do so (see Roe, 1999). In other words, security becomes a club good, and the state, having lost its monopoly, has to compete for shares in the market as one actor among many.

Moreover, in such a context, borders no longer define the sovereign sphere of state institutions. Violent groups partition the country's territory or battle for access to strategically profitable areas. Transboundary formations (Callagy et al., 2001) may create new types of authority in which ethnic belonging or clientelism determines access to the security provided by violent groups.

We argue that one way to conceptualize types of security is to examine organizational processes of resource extraction and allocation (i.e. the interaction between violent groups and the civilian population) and the territorial expansion of security provision. Analytically, this approach comprises four key questions: (1) Who provides security? (2) How is this provision organized militarily? (3) Is this provision territorially limited or does it expand over time? (4) What institutional means are applied in the interaction between the violent group and the civilian population?

Territoriality and the extent of consumption of specific protective measures are not only closely interconnected but also constitute the core elements for the identification of areas of strategic security or insecurity. However, territorial control and the ability to reduce external threats do not in and of themselves constitute a seal of approval for the quality of security, since the control of the use of force can also be used for indiscriminate violence (Kalyvas, 2006) and systematic slaughter of the population. Though selective violence against civilians constitutes an act of communication, signalling the armed actor's willingness and capability to control (Kalyvas, 2006: 26), in contrast, indiscriminate violence will take place under spatio-temporal conditions in which armed actors lack the information necessary to distinguish between 'good' and 'bad' civilians - that is, between civilians that are willing to collaborate or to defect (see Kalyvas, 2006: 150, 204). Accordingly, Kalyvas assumes that collaboration is mainly determined by effective control exercised by a capable armed actor: 'Gaining control over an area brings collaboration, and losing control of an area brings much of that collaboration to an end' (Kalyvas: 2006: 119). If we adopt this logic of violence, two presumptions become important: first, there must always be at least one armed actor, who intends to invest in security for a defined civilian population, rather than to exterminate or deport that population (Kalyvas, 2006: 28-31); second, even civilians act strategically in that they seek to remain 
alive in a secure environment (see also Weinstein, 2007). If this line of theoretical reasoning holds, civilians prefer to collaborate with the strongest armed group investing in protective means.

As long as rebels or local militias provide security only sporadically and in a territorially undefined context, security remains a rival commodity that can be excluded from consumption (Brauer, 1999: 6-7). Nevertheless, there are ways out of insecurity and the 'protection screw' (Mehlum et al., 2002: 448) that permit security as a good to once again move markedly from the private toward the public realm.

If we define security governance as the intentional provision of security for the collective good of a defined group of recipients of protection, one particular mode of security by coercion meets this criterion. Coercive security involves specific strategies on the part of militarily potent actors who invest in the establishment of monopolies in the use of force and thereby advance processes of governance formation. Primarily, dominant armed actors that are capable of imposing sanctions use their abilities to control territory and social relations (i.e. the civilian population) in order to build up internal and external protection systems. In addition, they no longer finance themselves by means of organized looting, but rather through institutionalized taxation systems. As long as these monopolists assure that the provision of security in their territory is not challenged or substituted by others, this system of rule can be treated as security governance. Typical examples are rebel groups such as the Sudan People's Liberation Army (SPLA) in Southern Sudan or the Revolutionary Armed Forces of Colombia (FARC). Furthermore, even local warlord factions in Afghanistan or Somalia have invested in the establishment of political and social regulatory structures that produce both a certain degree of mutual expectations and collectively binding decisions for a defined group.

\section{The logic of security markets}

Security and protection are not ordinary market commodities and differ in many ways from other consumer goods. While security can be seen as an aggregate state characterized by the absence of physical violence towards a defined group over time, protection encompasses all measures necessary for the creation of security. Protection is thus the active process of providing security and the major asset traded on security markets. The competition in the provision of protection differs from classic economic concepts in terms of the factors of production, pricing mechanisms and the resulting quality of the market product (Skaperdas and Konrad, 2004). Private protection providers do not compete via pricing mechanisms, but rather through the use of violent means to gain control of territory and the revenues resulting from protection services. Moreover, it must be taken into account that the ownership of goods and services is not exchanged voluntarily, but is instead acquired by force (Elwert, 1999: 87). Unlike ordinary commodity markets, greater competition in the protectionproviders' segment leads not to decreasing but rather to increasing prices for consumers of protection (Skaperdas, 2001: 174). At the same time, competition between non-state armed actors without a regulating central authority means that security dilemmas and arms races arise, which favour an increase in violence. Without any effective protection of their lives or property rights, large segments of the population are prevented from engaging in economically productive activities and are forced instead to invest in protecting themselves (Bates et al., 2002: 613). This need to invest in the means of violence reduces economic productivity and efficiency (Skaperdas, 2001: 187). Under conditions of overt violence, resources cannot be effectively distributed. Survival and the possibilities of profiting from the provision of protection services thus depend on one's relative ability to exercise violent control of resources and social relations where the state is no longer capable of doing so. Violence becomes a necessary - albeit not a sufficient - condition for the ability to 
participate as a competitive player in the security market. Within this context, the self-defence groups that have arisen in Afghanistan to enable individuals to protect themselves against attacks from the Taliban and/or units of the Northern Alliance must be considered as security market participants, just like better militarily equipped and hierarchically organized rebel groups.

The spectrum of market participants can be extended even further. In sub-Saharan Africa, this category includes not only rebel groups and local militias but also criminal cartels, traditional fighters like the Kamajors in Sierra Leone, and ad hoc groupings such as the so-called Area Boys in Lagos (Nigeria), who collect protection money on transportation routes and at weekly markets. Another critical group of actors that is contributing to the increased complexity of security markets and conflict structures in war, as well as in post-conflict and peacebuilding settings, is that of private military companies (PMCs). Highly specialized PMCs not only offer a variety of services on today's security markets, but also operate according to free-enterprise calculations. Internationally operating companies like Xe or DynCorp are the visible expression of a system that delegates selected security functions to commercial enterprises by states or private groups (see, for example, Avant, 2005; Leander, 2003; Musah, 2002; Singer, 2003). The involvement of this group of actors affects military power relationship and local conflict dynamics, as well as the calculations of state and non-state actors regarding whether to outsource certain forms of military activity to private specialists. These security dynamics turn out to have particularly serious consequences in Colombia and Iraq: external interventionists who support internal armed groups become themselves competitors for resources and aggravate both the available informational asymmetries and the intensity of conflicts.

From the perspective of conflict theory, the problem underlying the increase in the number of armed actors is that reliable information about competitive groups and mutually binding security guarantees become increasingly indeterminate (see, for example, Cunningham, 2006; Walter, 1997). The greater the number of potentially violent state and non-state parties to a conflict, and the more intense the competition becomes, the more significant are informational asymmetries and commitment problems. Such dynamics not only affect the conflict behaviour of armed actors but also heighten the vulnerability of societal groups (i.e. the civilian population) that are unable to provide for their own security by private means. Furthermore, the number of belligerents and their distribution of territorial control and military capabilities are also relevant to the relative power dynamics and expected outcomes of military strategies. As the application of bargaining power to civil contests shows (Butler and Gates, 2009), especially weaker non-state armed groups tend to invest in forms of unconventional warfare and engage in ongoing fighting against other parties. Given the asymmetric power dynamics and informational blind spots in failed states, we should expect armed groups to adopt strategies of insecurity through continued military attacks on both other armed actors and the civilian population. As a given group gains in terms of relative power and territorial control, armed groups can alter their security strategies accordingly.

In terms of economic theory, the market structures in the security realm can be described as an unusual form of monopolistic competition: each group establishes its own spatially delimited monopoly of protection, in which it must provide credible proof of its ability to provide security (Skaperdas, 2001: 187). The prices that can be demanded for protection services are thus contingent on the number of armed actors, the degree of spatial separation between competitors, material opportunity structures and alternative options for action for the affected population (e.g. flight or the construction of self-defence units). More specifically, it can be expected that greater competition among armed actors will lead to greater investment in combat and increased information deficits, which again aggravate achieving credible commitments (Skaperdas, 2002: 435). 
Economic models assume that decisionmakers - whether they are armed actors or potential entrepreneurs of governance - will consider the relative benefits of two forms of economic activity: investments in the production of civilian goods and services or investments in conflict-perpetuating means. Violent actors can thereby choose between the institutionalization of a rudimentary system of rule, one that guarantees ownership rights and organizes the interaction between providers and recipients of protection via a tax system, or a violence-mediated state of conflict, in which the civilian population is used as spoils, or as an extractable resource to finance the capability of these actors for violent activity.

But, even under the conditions of armed contest between two or more violent groups, temporary forms of cooperation or the evolution, by agreement, of oligopolies of violence (Mehler, 2004) are possible. A prime example is the formation of a temporary alliance in Sierra Leone during the mid1990s between the government, the commercial security companies Gurkha Security Guards Ltd, Executive Outcomes and Sandline International, and the self-defence groups of the Kamajor militias, to fight the rebels of the Revolutionary United Front (RUF) (Abdullah and Muana, 1998: 185).

Fundamentally, these considerations mean that armed groups can strategically choose between the provision of security and the maintenance of insecurity. The more promising military and economic profits become, and the more uncertain a future under the conditions of peace appears (Fearon, 2004), the higher the value of insecurity strategies should become. In view of the structural characteristics of insecurity, a reverted shadow of the future can be assumed, particularly in areas of warlord competition (Skaperdas, 2002: 444). The prospect of the elimination of competitors, and of the resulting greater profits, increases the value of violent conflict strategies in comparison to negotiated settlements. This has fatal consequences for the civilian population. First, the demand for protection services rises with the increasing degree of insecurity, though the free choice of protection-providers is greatly limited. Second, the risk increases that actors in the conflict will turn to strategies of indiscriminate violence (Kalyvas, 2006; Olsen, 2007; Weinstein, 2007; Wood, 2008) and promote diffuse insecurity. Arbitrary violence and destruction of property are more probable in zones of strategic insecurity because of the asymmetric distribution of information and multiple material insecurities (Kalyvas, 2006; Skaperdas, 2001: 188; Weinstein, 2007). The ability to cause either security or insecurity (or both) becomes a political and economic resource, and hence an alternative source of power. As a result, the price for protection services increases with the military capabilities of potent armed actors (Mehlum et al., 2002). Theoretically, the production of (in)security is thus immediately tied to the logic of violence and resource extraction.

In the context of an increasing tendency toward fragmentation of the actors' spectrum, as well as the associated implications for the forms of security, the concept of the security market describes the structure and composition of the supply-and-demand side in the provision of protection commodities and its temporal and spatial coincidence in areas where the provision is not monopolized. While a constant demand for security can be assumed on these markets, the supply varies in degree and over time. Similar to corporations on regular markets, violent groups calculate the profit margins of their investments in the supply of security - that is, whether to invest in the production of a secure environment (areas of strategic security) or to perpetuate the violent appropriation of resources. The inherent logic of security markets is described in Figure 1.

The breakdown of state institutions and the effective monopoly of violence at $t_{0}$ have two major implications: It leads to a fragmentation of the range of actors that formulate political and/ or economic claims, and it opens up the security market to non-state actors, owing to the absence of an effective monopoly of violence. We expect an increase in the total number of violent groups and more violence in the direct aftermath of state failure. Owing to the absence of a 


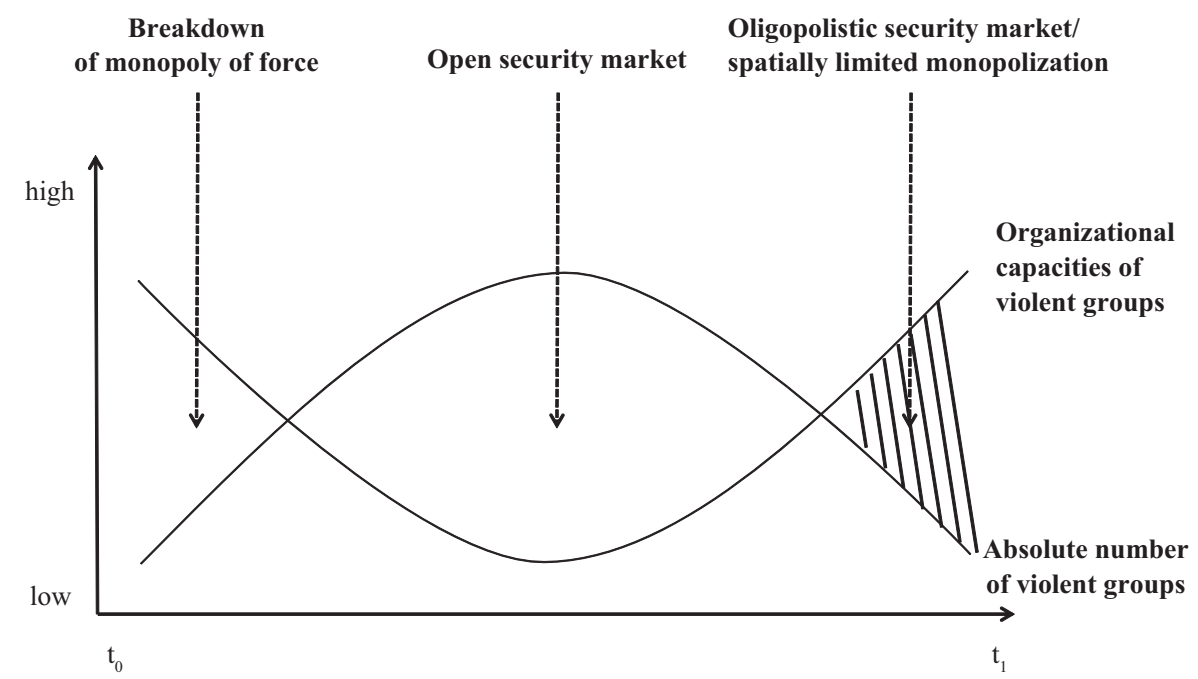

Figure I. The logic of security markets over time

sanctioning monopoly of violence, the incentives are high to enter the market and make use of freely accessible resources. In particular, escalation periods tend to be characterized by an apparently arbitrary plundering effort and the use of violence against civilians. These dynamics have two implications: First, the lower the profits get for individual violent groups, the higher the incentives to reduce the number of competitors. Violent groups are expected to engage in more battles as the number of local market participants increases. Second, more military resources are needed to defeat enemies, so the groups shift all of their resources to their military wings. The military organization increases in size. In accordance with such an increase, the cost of maintaining organizational capacities also increases. Thus, there is an incentive for a more efficient resource allocation, since the formerly applied strategies of resource extraction may not cover the expenses. At $t_{1}$ we expect an increase in the probability of coercive modes of governance, in which protection is offered and a rudimentary taxation system is implemented. As a result, roving bandits may decide to become stationary (Olson, 1993).

This way of theorizing the conditions for the institutionalizing of the provision of security as a public good is closely related to Olson's ideas (1993) and to what Charles Tilly (1985: 181) conceptualized as the four main activities the agents of states carry out. To guarantee that security or the use of force is not substituted by competitors, violent groups in fact aim to eliminate or neutralize their rivals outside (war-making) and inside (state-making) in 'the territories, in which they have clear and continuous priority, as wielders of force' (Tilly, 1985: 181). The monopolistic status that accompanies these activities allows them to provide security as a public good inside this territory (protection). To acquire the means for carrying out these activities, they extract resources from their client population through a taxation system (extraction). The evolution of nation-states is ultimately said to be a function of the mutual reinforcement of these activities. However, while Olson (1993) did not specify the precise switching point at which roving bandits become stationary (Kurrild-Klitgaard and Svendsen, 2003: 257), in Tilly's (1985: 172) account the growth of state organizations proceeds rather randomly and is said to be a path-dependent function of the demand for military capabilities to defeat adversaries. Although this institutional logic might not 
necessarily apply to the civil wars of the 21 st century (Sørensen, 2001), we follow this idea insofar as maintenance costs do in fact lead to an incentive to organize a more efficient extraction of resources, since a greater organization acquires greater costs. Thus, the logic of security markets does not necessarily entail an evolutionary logic to state-making, in that the types of security discussed here might not be embryonic to statehood - although they can be. In contrast to Tilly, we assume that there is no path dependency between organizational growth and state-making. Authority by violent groups can be temporally and spatially limited and is by no means always stable. The stability and the institutional development of coercive modes of governance depend instead on the time horizon (Frohlich and Oppenheimer, 1974). If a violent organization expects to stay in control indefinitely, then the optimal strategy is to tax appropriately and not to confiscate everything produced by the civilian population.

If security is ranked in a hierarchy of public good as the central precondition for a functioning political order (Konrad and Skaperdas, 2005; Rotberg, 2003), which is necessary to obtain positive effects in other realms, it follows that its rudimentary institutionalization can be restricted to the establishment of a system of protection and taxation. This implies formal and informal institutions that organize the monetary transactions between the provider and the recipients of protection, as well as an organizational framework that guarantees territorial integrity towards third parties. From a neo-institutionalist perspective this process gives rise to security expectations on the part of both the civilian population and the dominant armed actor. The civilian population can assume, on the basis of information regarding the military capacities of the protection-provider, a certain degree of effectiveness - that is, the protection-provider in fact appears as a reliable security monopolist in the eyes of the population (Weinstein, 2007: 169-70). Moreover, it is assumed that the productivity of the civilian population will increase owing to the perceived territorial security, since more time and resources can be invested in production than in self-protective means. In turn, the armed organization achieves reliability regarding a regular income, which it obtains through the institutionalized taxation system. In this way, armed groups not only secure their own organizational structures but also take into account future investment decisions, which can therefore take on the quality of a public good - if the investments are made through sustainable economic means of production (Kurrild-Klitgaard and Svendsen, 2003; Olson, 1993). To sum up, the success or stability of such non-state control systems depends on the quality of formal and informal rules of decisionmaking related to the system of protection and taxation, the credibility of deterrence of internal and external military challengers, and the reliability of agreements between the military leadership and the civilian population. Over time, however, even violent actors have to engage in legitimatizing processes. Theoretically, it can be assumed that coercive modes of security governance tend to establish an endogenous or exogenous frame of stabilization. Related to the former, an expansion of public-related services into other sectors (e.g. finance, health, education) characterizes the development of quasi-state structures (as, for example, in Somaliland) that require a minimum of output legitimacy (Bakonyi and Stuvøy, 2005). In the case of exogenous stabilization, one has to consider the benefits that accompany statehood (e.g. licensing, credits, development aid). From this point of view, it is not surprising that coercive modes of security governance may possibly transform into statehood (as occurred in Liberia with Charles Taylor) and make use of externally guaranteed sovereignty.

\section{Security by opportunity}

The dynamics described above are endogenous to the market, as they capture the quantity and quality of the constitutive market participants only. Yet, just as market conditions such as size of the market, 
sales prospects and sales volume frame the supply strategies of corporations in relation to product markets, so do specific opportunity structures enable and restrict the willingness to act within the domain of security markets. From a methodological perspective, opportunity structures should be considered as triggering, intervening or conditional variables that need additional elaboration.

Theoretically, opportunity structures encompass the conditions upon which actors formulate preferences, make decisions and act (Collier and Hoeffler, 1998; Siverson and Starr, 1991). In the research on the causes of war, they have often been used as explanatory factors for the probability of the outbreak of both internal and international warfare. However, both the twin concepts of opportunity and willingness developed by Benjamin Most and Harvey Starr (Most and Starr, 1980; Starr, 1978) and the opportunity model of the World Bank group around Paul Collier (Collier and Hoeffler, 1998, 2004) are oriented toward the relatively static boundary conditions of methodological nationalism (including borders, number of neighbouring states or primary goods exports). The approach developed by the World Bank group relates the motivation of armed actors primarily to the motive greed and the relative share of the export of primary goods to the overall volume of export (see the critique by Cramer, 2002; Fearon, 2005). Moreover, Collier and Hoeffler (1998) see structures of opportunity as pre-existing factors in conflicts between rebel groups and governments, which primarily reflect the conditions that increase the risk of the outbreak of civil wars involving two conflicting parties. But, precisely under the conditions experienced by failing states, opportunity structures and the configuration of actors may shift both in time and in space. Resources may be completely exploited, the emergence of splinter factions and/or the intervention of external actors may change the balance of power between conflicting parties, or one of these parties may over time establish a dominant position within a defined territory. The term 'opportunity structures' is therefore used as a broad category, encompassing the material, territorial and process-related options actors find under particular conditions of time and space. It refers both to incentive structures favouring the perpetuation of violence and to those factors that promote new modes of governance.

\section{Economic opportunities}

Basically, material structures of opportunity refer to all available resources that can be extracted and thus used to guarantee one's capability to exert force. Areas of strategic insecurity are therefore most likely to arise in resource-rich areas: the greater the wealth of resources, the higher the probability that new entrepreneurs of violence will appear on the security market and compete with one another. Consequently, the incentive structure to continuously apply military force and to produce insecurity will be greater. The insight that the type of resource itself affects the risks of the occurrence and perpetuation of organized violence is even more fundamental. Empirical studies reveal that the effect of diamonds and oil is highly significant, while that of agricultural goods, by contrast, is hardly significant at all (Fearon, 2005; Lujala et al., 2005; Ross, 2004). The extraction practice of guaranteeing one's own freedom to act by mining mineral resources leads to a different logic of security and different constraints than does the looting of the civilian population. While the extraction of natural resources primarily poses logistical challenges, such as the securing of extraction, storage sites and transportation routes, the taxation of humanitarian aid and looting of the civilian population tend to be carried out in a more ad hoc and often uncoordinated manner.

Resources are also a critical quantum for the survival of the civilian population and various types of armed organizations. Particularly, specialized entrepreneurs of violence make profits from lootings and protection services, thus jacking up the 'protection screw' (Mehlum et al., 2002). Looting has a dual function here: first, it enables better mobilization of resources to permit the financing of combat; second, it permits expenditures for the pay to combatants to be reduced (see, 
for example, Azam, 2006). In the long run, however, the looting of the civilian population also raises two problems: first, the number of competitive armed groups can increase over time, and hence too the number of violent incidents; second, this situation permits no phases of regeneration for the population, during which they can produce new resources to loot. Both problems imply a marginal profitability of looting over time.

By contrast, in areas with only weakly organized armed groups, the civilian population can, theoretically, be considered as a freely accessible resource, and as such is constantly endangered by overlooting (Kurrild-Klitgaard and Svendsen, 2003: 257). In situations of competition between armed groups, these conditions intensify. Under conditions of incomplete information, armed groups most likely come to no mutual agreement as to where and to what degree looting is to be undertaken. Hence, the probability of overlooting increases. A sustainable practice of extraction, which allows for regeneration phases for the population, can hardly be expected in situations in which armed groups are highly fractured into splinter factions and in which there is a high demand for resources and specific organizational structures.

These issues are closely related to organizational dynamics. For every armed group, an increased degree of organization implies higher maintenance expenses and hence an increased demand for resources. The marginal profitability of looting can therefore occur in a dual manner: first, via overlooting as described above, by which non-coordinated looting and the potential increase of armed groups result in overplundering and the loss of potential profits; and, second, when profits no longer cover the regular expenditures of maintenance. According to economic theory, the positive, beneficial effects for the civilian population increase with a minimum of security, since it can invest in production rather than protection services. A well-established armed organization can therefore seize a dominant position in the course of the conflict and take the opportunity to share in the profits of increased productivity through taxation of protection in a defined territory.

\section{Geographic opportunities}

Recent civil war research has discovered the 'geography of war'. Studies show that topographical variables like forests and mountains not only affect the manner in which internal conflicts are carried out, but are also important in determining the prospect of winning a battle or the war (Buhaug and Gates, 2002; Buhaug and Rød, 2006; Gates, 2002). At the same time, geography also limits the number of potential violent actors and provides information for an understanding of organizational logics of violent groups. Greater distance between contending groups affects the probability that competing violent groups will emerge (Gates, 2002: 127).

Particularly linked to geographic opportunity structures is the concentration of resources, which affects the possibilities of carrying out certain forms of violent control and making profits from resource extraction. One has to bear in mind that natural resources differ considerably in their concentration and location (see, for example, Le Billon, 2001; Ross, 2004). Centralized resources such as petroleum and easily accessible mines are considerably easier to monitor than resources that are widely dispersed geographically, such as opium plantations, alluvial diamonds or tropical forests. A critical aspect is the proximity to the headquarters of a rebel group or the capital of the state. It has been demonstrated empirically that natural resources that are located near the capital of a country can be monitored more easily by the sitting government than more remote extraction sites (Le Billon, 2001). The reverse is equally the case: the further an extraction site is away from the state centre, the easier it is for non-state armed groups to appropriate, and the more probable it will be that violent conflicts, and hence areas of strategic insecurity, arise. Accordingly, geographic opportunities influence the size and dispersion of violent groups in very different ways. They determine 
to what degree violent groups can rely on direct extraction means, such as the plunder of agricultural products during harvesting time, or whether indirect means of extraction (taxation of international relief supplies or protection duties on transportation routes) are applied.

\section{Conflict-related opportunities}

Conflict-related opportunities refer to characteristics of the course of conflict, such as its intensity or its duration, and are critical process conditions for the evolution of security governance. Through defeating their enemies or conquering major parts of the conflict zone, armed groups may achieve a dominant position during a conflict and come closer to the ability to monopolize the use of force. Extended conflicts can in turn provoke external military interventions by third parties (Regan, 2000), which might either change the military balance or even imply an externally induced institutionalization of a security order of another kind (e.g. protectorates, peacemaking missions, etc.). Since rebel groups are said to have a decreased probability of winning wars after UN interventions, as the likelihood of a treaty or truce increases (De Rouen and Sobek, 2004), violent groups might seek to increase their legitimacy and refrain from looting and plundering.

Civil wars in which multiple actors have to approve a settlement tend to be longer, because of a low degree of willingness to accept agreements, greater information asymmetries, and shifting incentives and alliances (Cunningham, 2006). The duration of violent conflicts and the number of participating actors (veto players) are thus of critical importance, since they tend to increase the likelihood of (1) violence against civilians (looting) and (2) overlooting. The effect of the active number of actors is underestimated in recent civil war studies (Azam and Hoeffler, 2002; Eck and Hultman, 2007; Kalyvas, 2006; Valentino et al., 2004; Weinstein, 2007). This literature remains state-centred and focuses on conflicts between governments and rebel groups. However, failed states are often not characterized by a dyadic conflict structure (state vs rebel group). Instead, the state's control of the use of force is severely limited or has broken down, and several entrepreneurs of violence compete as providers of security or perpetrators of insecurity. Assuming a multipleactor setting, a decrease in the number of violent groups should, over time, imply an increase in the relative power position and the organizational size of other actors, which in turn should positively affect the probability of coercive security. The function of violence again changes in such situations. Whereas fighting and battles are used to signal one's own military capabilities and gather information about the adversary (Powell, 2004; Wagner, 2000), the strategic use of violence might switch to the defence of territory and attacks against enemies who attempt to conquer already controlled areas.

In sum, conflict-related opportunities point to the fact that the conflict setting (duration, domination, intervention) and the available resources (long-run negative externalities of plundering) change over time. This confronts violent groups with an incentive to invest in the buildup of areas of strategic security rather than perpetuate strategies of plundering and looting.

\section{Conclusion}

As this article has argued, there is an inherent logic to security markets that predicts the emergence of security governance in failed states. The variance of the overall number of armed groups and their organizational capacity explains the tendency either to use violence against the civilian population for resource-allocation purposes or to invest in the provision of security by establishing coercive modes of governance. State collapse should be understood as a specific structural characteristic, since it opens the security market up to non-state actors, who might enrich themselves and 
use violence in the absence of a sanctioning authority. In the long run, the increase in the number of actors and their organizational demands creates a problem in resource allocation, as well as additional incentives to use nonviolent means of extraction and invest in the provision of security governance. Changing geographical, economic and conflict-related structures of opportunity frame this endogenous market logic. The establishing of governance should be expected as a preferred strategy for exerting control over a defined territory and a defined population under certain material conditions (i.e. within economically valuable territories), in order to overcome or balance the risks of survival and negative economic effects (overplundering) in zones of permanent violence. The formation of security structures may fail or become the unmaking of governance, if armed groups refrain from providing both a minimum of internal security and deterrence from external threats, resources are limited or become scarce, and support within the armed group or population decreases. While Somaliland (since 1991) and Puntland (since 1998) clearly represent alternative forms of security governance beyond the state, partially institutionalized macro-networks of strategic security such as 'Taylor-Land' in Liberia (1991-6), 'Nkunda-Land' (2004-9) in the Eastern Congo or the Islamic Courts in Somalia (1999-2006) stand for the attempt to invest in the provision of security within failed states and for the failure or transitional character of such security arrangements.

The potential paths of governance formation discussed here suggest, first, that the provision of security as a governance service can be provided by a variety of non-state groups without the state; second, that it may be organized on the basis of rudimentary regulatory structures and processes; and, third, that it varies in its effective range (territoriality and consumption). We are well aware, however, that the building of security governance or 'rebel governments' (Weinstein, 2007: 164) may also include other opportunity structures, such as shared identities and social institutions. For example, civilian involvement in the building of governance may greatly enhance armed groups' responsiveness to the needs of civilian populations: for northern and northwestern Liberia, Amos Sawyer (2005) describes how the Poro authority and armed rule was used to build governance structures and to integrate armed groups into local power structures, while at the same time restricting their military actions.

Conceptually, the considerations presented here indicate conscious points of reference on the concept of markets of violence (Elwert, 1999), and on what Pegg (1998), Lynch (2004), Berg (2007) and others have called de facto states, or what Kingston and Spears (2004) term states-within-states, and Kolstø (2006) terms unrecognized quasi-states. Against this backdrop, Jutta Bakonyi and Kirsti Stuvøy $(2005,2006)$ distinguish between two ideal types of non-state orders of violence: warlord configurations, which constitute an only weakly institutionalized type of order, are not territorially consolidated and hardly have any organizational apparatus, and quasi-states, which are best characterized as highly institutionalized orders of violence akin to basic functions of the state, but that may not enjoy formal recognition by the international community (such as Somaliland). Nonetheless, quasi-states have monopolized the provision of security within their territorial areas of influence and control parts of a territory, together with its economic resources (see Bakonyi and Stuvøy, 2006: 41-2). Both variants ultimately indicate the co-existence of alternative structures of order in failed states. Yet, that does not mean that the state loses its significance entirely in such areas. It may very well remain the central frame of reference for non-state armed actors and also fits well into the logic of structures of opportunity. The state apparatus and the perspective of international recognition remain important resources, both internally (political legitimacy, advantages over political rivals) and externally (e.g. in the form of international financial aid or access to international assistance). It can therefore be assumed that opportunity structures such as the form of a state and the norm of sovereignty will in the future continue to determine the options for action of (some) private armed groups. 


\section{Acknowledgements}

The authors would like to thank Thomas Risse, Claire Cutler, Susan Sell, Deborah Avant, Tobias Debiel, Elke Krahmann and the participants of the research seminar at the Institute for Global and International Studies (IGIS) for their helpful comments. Finally, we thank Gregor Reisch for his research assistance.

\section{Funding}

This work was funded by the German Science Foundation [SFB700].

\section{References}

Abdullah I and Muana P (1998) The Revolutionary Front of Sierra Leone: A revolt of the lumpenproletariat. In: Clapham C (ed.) African Guerillas. Oxford: James Currey, 172-195.

Avant DD (2005) The Market for Force: The Consequences of Privatizing Security. Cambridge: Cambridge University Press.

Azam JP and Hoeffler A (2002) Violence against civilians in civil wars: Looting or terror? Journal of Peace Research 39(4): 461-485.

Azam JP (2006) On thugs and heroes: Why warlords victimize their own civilians. Economics of Governance 7(1): 53-73.

Bakonyi J and Stuvøy K (2005) Violence and social order beyond the state: Somalia and Angola. Review of African Political Economy 32(104): 359-382.

Bakonyi J and Stuvøy K (2006) Zwischen Warlordfigurationen und Quasi-Staat. Ansätze zu einer Typologie bewaffneter Gruppen [Between warlord configurations and quasi-states: Approaches to a typology of armed groups]. In: Bakonyi J, Hensell S and Siegelberg J (eds) Gewaltordnungen bewaffneter Gruppen. Ökonomie und Herrschaft nichtstaatlicher Akteure in den Kriegen der Gegenwart [Violence-Based Order Systems of Armed Groups: Economy and Power of Non-State Groups in Today's Wars]. Baden-Baden: Nomos, 38-52.

Bates R, Greif A and Singh S (2002) Organizing violence. Journal of Conflict Resolution 46(5): 599-628.

Berg E (2007) Examining power-sharing in persistent conflicts: De facto pseudo-statehood versus de jure quasi-federalism. Global Society 21(2): 199-217.

Brauer J (1999) An economic perspective on mercenaries, military companies, and the privatisation of force. Cambridge Review of International Affairs 13(1): 130-146.

Buhaug H and Gates S (2002) The geography of civil war. Journal of Peace Research 39(4): 417-433.

Buhaug H and Rød JK (2006) Determinants of African civil wars, 1970-2001. Political Geography 25(3): 315-335.

Butler CK and Gates S (2009) Asymmetry, parity, and (civil) war: Can international theories of power help us understand civil war? International Interactions 35(3): 330-340.

Callagy T, Kassimir R and Latham R (eds) (2001) Intervention and Transnationalism in Africa: Global and Local Networks of Power. Cambridge: Cambridge University Press.

Collier P and Hoeffler A (1998) On the economic cause of civil war. Oxford Economic Papers 50(4): 563-573.

Collier P and Hoeffler A (2004) Greed and grievance in civil war. Oxford Economic Papers 56(4): 563-595.

Cramer C (2002) Homo economicus goes to war: Methodological individualism, rational choice and the political economy of war. World Development 30(11): 1845-1864.

Cunningham DE (2006) Veto players and civil war duration. American Journal of Political Science 50(4): 875-892.

De Rouen KJR and Sobek D (2004) The dynamics of civil war duration and outcome. Journal of Peace Research 41(3): 303-320. 
Duffield M (2001) Global Governance and the New Wars: The Merging of Development and Security. London: Zed.

Eck K and Hultman L (2007) One-sided violence against civilians in war: Insights from new fatality data. Journal of Peace Research 44(2): 233-246.

Elwert G (1999) Markets of violence. In: Elwert G, Feuchtwang S and Neubert D (eds) Dynamics of Violence: Processes of Escalation and De-escalation in Violent Group Conflicts. Berlin: Duncker and Humblot, 85-102.

Fearon JD (2004) Why do some civil wars last so much longer than others? Journal of Peace Research 41(3): $275-301$.

Fearon JD (2005) Primary commodity exports and civil war. Journal of Conflict Resolution 49(4): 483-507.

Frohlich N and Oppenheimer J (1974) The carrot and the stick: Optimal program mixes for entrepreneurial political leaders. Public Choice 19(1): 43-61.

Gates S (2002) Recruitment and allegiance: The microfoundations of rebellion. Journal of Conflict Resolution 46(1): 111-130.

Jackson P (2003) Warlords as alternative forms of governance. Small Wars and Insurgencies 14(2): 131-150. Kalyvas SN (2006) The Logic of Violence in Civil War. Cambridge: Cambridge University Press.

Kaufman SJ (1996) An international theory of inter-ethnic war. Review of International Studies 22(2): 149-171. Keen D (2000) Incentives and disincentives for violence. In: Berdal MR and Malone D (eds) Greed and Grievance: Economic Agendas in Civil Wars. Boulder, CO: Lynne Rienner, 19-41.

Kingston P and Spears I (eds) (2004) States Within States: Incipient Political Entities in the Post-Cold War Era. New York: Palgrave Macmillan.

Kolstø P (2006) The sustainability and future of unrecognized quasi-states. Journal of Peace Research 43(6): 723-740.

Konrad KA and Skaperdas S (2005) The market for protection and the origin of the state. CESIFO Working Paper no. 1578. Available at: http://www.cesifo-group.de/portal/pls/portal/docs/1/1188516.PDF (accessed 19 August 2011).

Krahmann E (2008) Security: Collective good or commodity? European Journal of International Relations 14(3): 379-404.

Kurrild-Klitgaard P and Svendsen GT (2003) Rational bandits: Plunder, public goods, and the Vikings. Public Choice 117(3-4): 255-272.

Le Billon P (2001) The political ecology of war: Natural resources and armed conflicts. Political Geography 20(5): 561-584.

Leander A (2003) The commodification of violence: Private military companies and African states: In: Muchie M (ed.) The Making of the Africa-Nation: Pan-Africanism and the African Renaissance, London: Adonis-Abbey, 264-280.

Lujala P, Gleditsch NP and Gilmore E (2005) A diamond curse? Civil war and a lootable resource. Journal of Conflict Resolution 49(4): 538-562.

Lynch D (2004) Engaging Eurasia's Separatist States: Unresolved Conflicts and De Facto States. Washington, DC: United States Institute of Peace Press.

Mehler A (2004) Oligopolies of violence in Africa south of the Sahara. NORD-SÜD Aktuell 18(3): 539-548.

Mehlum H, Moene K and Torvik R (2002) Plunder and Protection Inc. Journal of Peace Research 39(4): 447-459.

Most BA and Starr H (1980) Diffusion, reinforcement, geo-politics and the spread of war. American Political Science Review 74(4): 932-946.

Musah AF (2002) Privatization of security, arms proliferation and the process of state collapse in Africa. Development and Change 33(5): 911-933. 
Öberg M and Strøm K (2008) Introduction. In: Öberg M and Strøm K (eds) Resources, Governance and Civil Conflict. London: Routledge, 1-22.

Olsen KT (2007) Violence against civilians in civil war: Understanding atrocities by the Lord's Resistance Army in Northern Uganda. Conflict Research Group Working Paper Nr. 8. Gent: Conflict Research Group (CRG) at the University of Ghent (Faculty of Political and Social Sciences). Available at: http://www.psw. ugent.be/crg/index.html (accessed 1 September 2011).

Olson M (1993) Dictatorship, democracy, and development. American Political Science Review 87(3): 567-576. Ottaway KT (2002) Rebuilding state institutions in collapsed states. Development and Change 33(5): 1001-1023. Pegg S (1998) International Society and the De Facto State. Aldershot: Ashgate.

Posen B (1993) The security dilemma and ethnic conflict. Survival 35(1): 27-47.

Powell R (2004) Bargaining and learning while fighting. American Journal of Political Science 48(2): 344-361. Regan PM (2000) Civil Wars and Foreign Powers: Outside Interventions and Intrastate Conflict. Ann Arbor, MI: University of Michigan Press.

Reno W (2000) Shadow states and the political economy of civil war. In Berdal MR and Malone D (eds) Greed and Grievance: Economic Agendas in Civil Wars. Boulder, CO: Lynne Rienner, 43-68.

Risse T and Lehmkuhl U (eds) (forthcoming) Governing Without a State? Governance in Areas of Limited Statehood. New York: Columbia University Press.

Roe P (1999) The intrastate security dilemma: Ethnic conflict as a 'tragedy'. Journal of Peace Research 36(2): $183-202$.

Ross ML (2004) What do we know about natural resources and civil war? Journal of Peace Research 41(3): $337-356$.

Rotberg RI (2003) Failed states, collapsed states, weak states: Cause and indicators. In: Rotberg RI (ed.) State Failure and State Weakness in a Time of Terror. Cambridge: World Peace Foundation, 1-25.

Rothschild E (1995) What is security? Daedalus 124(4): 53-98.

Samuelson P (1954) The pure theory of public expenditure. The Review of Economics and Statistics 36(4): 387-389.

Sandler T (1993) The economic theory of alliances. Journal of Conflict Resolution 37(3): 446-483.

Sawyer A (2005) Social capital, survival strategies, and their potential for post-conflict governance in Liberia. Research Paper 2005/15. Helsinki: United Nations University - World Institute for Development Economics Research (WIDER).

Singer PW (2003) Corporate Warriors: The Rise of the Privatized Military Industry. Ithaca, NY: Cornell University Press.

Siverson RM and Starr H (1991) The Diffusion of War: A Study of Opportunity and Willingness. Ann Arbor, MI: University of Michigan Press.

Skaperdas S (2001) The political economy of organized crime: Providing protection when the state does not. Economics of Governance 2(3): 173-202.

Skaperdas S (2002) Warlord competition. Journal of Peace Research 39(4): 435-446.

Skaperdas S and Konrad K (2004) What kind of order out of anarchy? Self-protective security, autocracy, and predatory competition. Working Paper 2004. Berkeley, CA: Institute of Governmental Studies, University of California.

Sørensen G (2001) War making and state making in the Third World: Why doesn't it work in the Third World? Security Dialogue 32(3): 341-354.

Starr H (1978) 'Opportunity' and 'willingness' as ordering concepts in the study of war. International Interactions 4(4): 363-387.

Stiglitz JE (1999) Economics of the Public Sector, 3rd edn. New York: W. W. Norton.

Stokke K (2006) Building the Tamil Eelam state: Emerging state institutions and forms of governance in LTTE-controlled areas in Sri Lanka. Third World Quarterly 27(6): 1021-1040. 
Tilly C (1985) War making and state making as organized crime. In: Evans P, Rueschmeyer D and Skocpol T (eds) Bringing the State Back In. Cambridge: Cambridge University Press, 169-191.

Tilly C (1990) Coercion, Capital, and the European State, AD 990-1990. Cambridge: Basil Blackwell.

Tull DM (2004) The Reconfiguration of Political Order in Postcolonial Africa: A Case Study from North Kivu (DR Congo). Doctoral dissertation. University of Hamburg.

Valentino B, Huth P and Balch-Lindsay D (2004) 'Draining the sea': Mass killing and guerrilla warfare. International Organization 58(02): 375-407.

Vreeland JR (2008) The effect of political regime on civil war: Unpacking anocracy. Journal of Conflict Resolution 52(3): 401-425.

Wagner RH (2000) Bargaining and war. American Journal of Political Science 44(3): 469-484.

Walter BF (1997) The critical barrier to civil war settlement. International Organization 51(3): 335-364.

Weber M ([1921] 1968) Wirtschaft und Gesellschaft [Economy and Society]. Tübingen: Mohr.

Weinstein JM (2007) Inside Rebellion: The Politics of Insurgent Violence. Cambridge: Cambridge University Press.

Wood EJ (2008) The social processes of civil war: The wartime transformation of social networks. Annual Review of Political Science 11: 539-561.

Željko Branović is a Research Fellow at the Collaborative Research Center (SFB) 700: Governance in Areas of Limited Statehood.

Sven Chojnacki is Professor of Peace and Conflict Studies at the Free University Berlin (FU). 